$19: 1268$

例では, Urokinase 療法後に待期的再弁置換術が必要と 考えられる.中等度以上の心不全症例では，脳塞栓症の 誘発という重大な問題点があるため, Urokinase 療法の 適応決定に問題を残すが，今回の症例では投与中，投与 後早期の塞栓合併症は皆無であった.

\section{結語}

Björk-Shiley 弁置換後症例に抬いて臨床所見あるい は人工弁最大開放角測定により人工弁血栓症と判断され た症例に詨して Urokinase に上る血栓溶解療法を行っ た.

（1）軽度開放角制限例および無症状例は Urokinase 療法の好適応と考えられる.
19巻 6 号 (1990)

（2）無症状であるが開放角制限を繰り返す症例，無 症状であるが投与遠隔期に塞栓症を合併した症例では， Urokinase 療法後に待期的再弁置換術が必要と考えられ る.

（3）中等度以上の心不全症例では，脳塞栓症の誘発 という重大な問題点があるため適応決定に問題を残す が，今回の症例では投与中，投与㣪早期の塞栓合併症は 皆無であった。

文 献 1) Luluaga, I. T. et al.: Lancet 22: 1067, 1971. 2) Draur, R.A.: Am. Heart J. 108:605, $1984 . \quad 3)$ 難波宏 文ほか：日心外会誌 16:496, 1987. 4) Boskovic, D. et al.: J. Thorac. Cardiovasc. Surg. 91: 1, 1986. 5) 難波宏文: 岡山医誌 $100: 265 ， 1988.6)$ 難波宏文：岡山医誌 100：281, 1988.

\title{
335 血栓弁に対する外科治療
}

社会保険小倉記念病院 心臓血管外科, 京都大学附属病院 心臟血管外科*

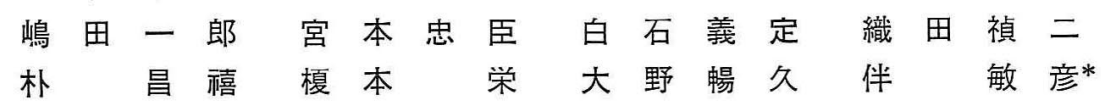

人工升置換後の血栓弁による弁機能不全はまれではあ るが対応が遅れると致命的になる重要な合作症の一つで ある.われわれの経験した血栓弁症例 10 例を報告する。

\section{対象亡方法}

'73 年 7 月より’88 年 12 月までの間, 856 例に 1049 個 の人工主置換術を行った. 図 1 のごとく'83 年までは Björk-Shiley 弁 (BS 弁) を, '84 年からは St. Jude
Medical 弁 (SJM 弁) と Carpentier-Edwards 弁を中 心に使用した。この間に確認した血栓弁症例は10例で， 初回于術時年齡は 27〜62 (可均 41.5) 歳, 2 例が男性, 8 例が女性であった．8例は当院で，2例は他院で弁置 換術を受けた．血栓弁の䛦断は 2 例で剖検時に行った. これらの初回手術および術後経過，抗凝固療法の適切 性，血栓弁発症前の症状，䛦断方法，手術時あるいは剖 検時所見，血栓弁手術後の経過等につき検討した。

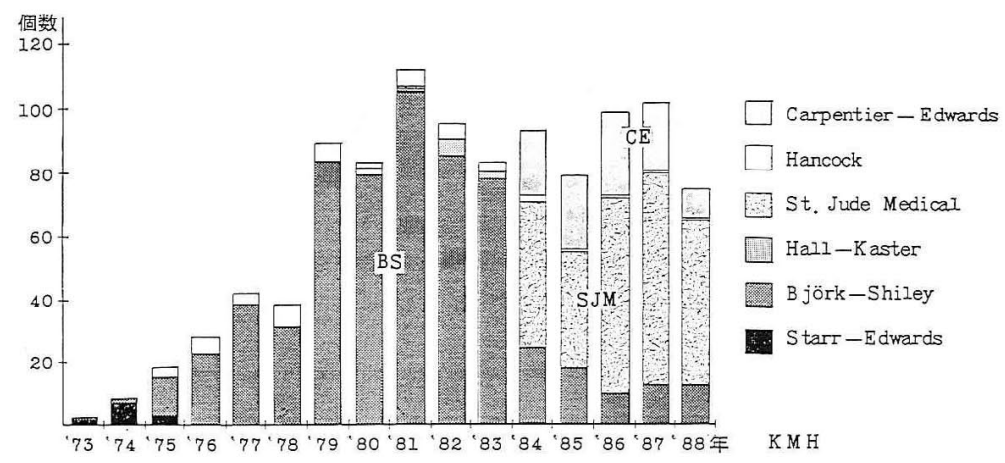

図 1 人工弁の変遷 
表 1

\begin{tabular}{|c|c|c|c|c|c|c|c|c|c|c|c|c|}
\hline \multirow{3}{*}{ 症例 } & \multicolumn{7}{|c|}{ 初 回手術 時 } & \multicolumn{2}{|c|}{ 抗凝固療法 } & \multicolumn{3}{|c|}{ 退院後経過 } \\
\hline & \multirow{2}{*}{\multicolumn{2}{|c|}{ 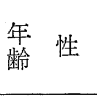 }} & \multirow{2}{*}{ 診断 } & \multirow{2}{*}{ 手術 } & \multirow{2}{*}{ 人工弁 } & \multirow{2}{*}{$\begin{array}{l}\text { large } \\
\text { opening }\end{array}$} & \multirow{2}{*}{ 調律 } & \multirow{2}{*}{$\begin{array}{l}\text { 投薬 } \\
\text { 内容 }\end{array}$} & \multirow{2}{*}{ 開始日 } & \multicolumn{2}{|c|}{ Wf control 不良時期 } & \multirow{2}{*}{ 塞栓症 } \\
\hline & & & & & & & & & & $\mathrm{TT}$ & 理由, 外科処置 & \\
\hline \multicolumn{13}{|c|}{ Aortic $(4 / 254=1.6 \%)$} \\
\hline 1. & 39 & $\mathrm{~F}$ & ASR & AVR & $\mathrm{BS} 19(\mathrm{~s})$ & $\mathrm{NCC}$ & $\mathrm{SR}$ & Wf & 3 pod & $\mathrm{n}$ & 子宮筋腫 Op & $\mathrm{n}$ \\
\hline 2. & 27 & $\mathrm{~F}$ & $\begin{array}{c}\text { AR } \\
\text { Aortitis }\end{array}$ & AVR & $\mathrm{BS} 25(\mathrm{~s})$ & NCC & $\mathrm{SR}$ & Wf & 2 pod & $82 \%$ & $\begin{array}{l}\text { 他院で } \\
\text { control 不良 }\end{array}$ & $\mathrm{n}$ \\
\hline 3. & 44 & $\mathrm{~F}$ & $\begin{array}{c}\text { AR } \\
\text { Aortitis }\end{array}$ & AVR & $\mathrm{BS} 23(\mathrm{~s})$ & $\mathrm{NCC}$ & SR & Wf & 2 pod & $100 \%$ & $\begin{array}{l}\text { 下血, 他院で } \\
\text { control 不良 }\end{array}$ & $\mathrm{n}$ \\
\hline 4. & 62 & $\mathrm{~F}$ & $\mathrm{ASr}$ & $\begin{array}{c}\text { AVR } \\
\text { IABP (LOS) }\end{array}$ & $\mathrm{BS} 21(\mathrm{~s})$ & NCC & SR & Wf & 4 pod & $100 \%$ & $\begin{array}{l}\text { 他院で } \\
\text { control 不良 }\end{array}$ & $\mathrm{n}$ \\
\hline \multicolumn{13}{|c|}{ Mitral $(2 / 266=0.8 \%)$} \\
\hline 5. & 54 & $\mathrm{~F}$ & $\begin{array}{l}\text { cTGA } \\
\text { anat. TR }\end{array}$ & $\begin{array}{c}\text { MVR } \\
\text { (anat. TVR) }\end{array}$ & $\mathrm{BS} 27(\mathrm{~s})$ & post & $\mathrm{SR}$ & Wf & 2 pod & $32 \%$ & $\begin{array}{l}\text { 肝障害の時期 } \\
\text { Wf 減量 }\end{array}$ & 脳梗塞 \\
\hline 6. & 52 & $\mathrm{M}$ & MS & MVR & $\mathrm{BS} 29(\mathrm{~s})$ & post & Af & Wf & 2 pod & $32 \%$ & $\begin{array}{l}\text { 鼻出血 } \\
\text { Wf 減量 }\end{array}$ & $\begin{array}{l}\text { 下肢 } \\
\text { 塞栓症 }\end{array}$ \\
\hline 7. & 36 & $\mathrm{~F}$ & $\begin{array}{l}\mathrm{MSr} \\
\mathrm{SBE}\end{array}$ & $\begin{array}{l}\text { MVR } \\
\text { TAP }\end{array}$ & $\mathrm{BS} 25(\mathrm{~m})$ & ant & $\mathrm{SR}$ & $\begin{array}{c}\text { Wf } \\
\text { As, Di }\end{array}$ & 1 pod & $\mathrm{n}$ & 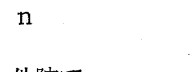 & $\mathrm{n}$ \\
\hline 8. & 32 & $\mathrm{~F}$ & $?$ & MVR* & $\mathrm{BS} 27(\mathrm{~s})$ & post & $\mathrm{SR}$ & $?$ & $?$ & $93 \%$ & $\begin{array}{l}\text { 他院で } \\
\text { control 不良 }\end{array}$ & TIA \\
\hline 9. & 60 & $\mathrm{M}$ & $?$ & MVR* & OS & post & $?$ & $?$ & $?$ & $73 \%$ & $\begin{array}{l}\text { 急性硬膜下血腫 } \\
\text { Wf 中止 }\end{array}$ & 脳梗塞 \\
\hline \multicolumn{13}{|c|}{ Tricuspid $(1 / 16=6.3 \%)$} \\
\hline 10. & 39 & $\mathrm{~F}$ & $\begin{array}{l}\text { TSr } \\
\text { MS } \\
\text { ARs }\end{array}$ & $\begin{array}{l}\text { TVR } \\
\text { MVR } \\
\text { AVR }\end{array}$ & $\mathrm{BS} 31(\mathrm{~s})$ & ant & Af & Wf & 2 pod & $30 \%$ & $\begin{array}{l}\text { 鼻出血 } \\
\text { Wf 減量 }\end{array}$ & $\mathrm{n}$ \\
\hline
\end{tabular}

平均 45.5 歳, * 他院で施行, ant: anterior, Wf : Warfarin, As : Aspirin, Di : Dipyridamole, post: posterior

\section{結 果}

表 1 のごとく病変部位および初回手術は大動脈 $(\mathrm{A})$ 弁 が症例 1 から4の4例で, いずれも AVR を, 修正大 血管転位の解剖学的三尖弁を1例含む僧帽 (M) 弁が症 例 5 から9の5例で, 内 4 例が MVR, 1 例が MVR+ TAP を，三尖 $(\mathrm{T})$ 弁が症例 10 の 1 例で AVR+MVR +TVR を施行していた. 人工弁はすべて tilting disc 型で症例 7 の monostrut $(\mathrm{m})$ 型 BS 弁, 症例 9 の Ommiscience (OS) 弁を除き，他は spherical（s) 型 BS 弁であった.

この間当院で弁置換後生存して退院した症例の $\mathrm{S}$ 型 BS 弁は 537 個（A弁 254 個，M弁 266 個， T弁 16 個）で，血栓弁の頻度は全体で $1.3 \%$ （A弁 1.6\%， M弁 $0.8 \%$ ， T弁 6.3\%) であった. 弁の縫着方向は, large opening がA弁では無冠尖へ向くように，M弁で は， $\mathrm{m}$ 型 BS 弁以外は posterior へ向くように， T弁 では anterior へ向くようにした. 症例 4 で LOS のた めIABP を6日間使用したが，おおむね術後経過は良 好であった. 抗凝固療法は warfain で行い, 術後 1〜 4 日目に開始し，'84年からは抗血小板剂を併用してい
る. 多くの症例で術後 2 〜日目にトロンボテストが $25 \%$ 以下の治療域に達しているが，心カテーテル検査 等, 入院中短期間ではあるが $30 \%$ を越える症例が 8 例 中 6 例あった. 逆に症例 7 はトロンボテスト上理想的な 抗凝固療法であったが血栓弁で術後 13 日目に病院死し ている. 他は退院し外来通院していた.

うち 5 例は，急性硬膜下血腫，下血，紹介医あるいは 患者の認識不足等でトロンボテストが $70 \%$ 以上のきわ めて不良な状態が続き，てれが血栓弁発症の原因と考え る. $\mathrm{A}$ 弁, $\mathrm{M}$ 弁の血栓弁では, 呼吸困難, 全身僚意感な ごの左心不全症状をきたしたが，A弁ではこれに加え AS のためと思われる狭心痛あるいは胸痛を訴えるもの が 4 例中 3 例あった。

$\mathrm{M}$ 弁では全例塞栓症の既往があり，心房細動となって いた.

剖検例を除くと血栓弁の診断は, 初回手術後 5 か月〜 8 年 6 加月平均 4 年 9 か月時飞行われた. 診断上有力で あったのは cineradiography（透視）で，8例全例に行 い，7例で確定診断となった. Tantalum marker 付弁 の開放角と閉鎖角を相馬ら ${ }^{1)}$ の方法で測定したところ, $30^{\circ}$ 前後の開放角と $20^{\circ}$ 前後の閉鎖角が得られ，不完全 
19 : 1270

日本心臓血管外科学会雑誌 19 巻 6 号 (1990)

表 2

\begin{tabular}{|c|c|c|c|c|c|c|c|c|c|c|c|c|c|c|c|}
\hline \multirow{2}{*}{$\begin{array}{l}\text { 症 } \\
\text { 例 } \\
\end{array}$} & \multicolumn{4}{|c|}{ 血栓弁の診断時 } & \multirow{2}{*}{$\begin{array}{c}\text { 初回 Op } \\
\text { 加 } \\
\text { 期間 }\end{array}$} & \multirow{2}{*}{$\begin{array}{l}\text { 確定 } \\
\text { 熟断 } \\
\text { 方法 }\end{array}$} & \multirow{2}{*}{\multicolumn{2}{|c|}{$\begin{array}{l}\frac{\text { 透視による }}{\text { 開放 閉鎖 }} \\
\text { 角度 角度 }\end{array}$}} & \multirow{2}{*}{ 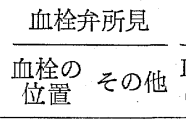 } & \multicolumn{6}{|c|}{ 血栓弁手術 } \\
\hline & 症 & 例 & $\begin{array}{l}\text { N Y } \\
\mathrm{HA}\end{array}$ & 調律 & & & & & & $\begin{array}{l}\text { Dx } מ \\
\text { 多 }\end{array}$ & 術式 & 人工弁 & 結果 $\frac{f}{u}$ & $\begin{array}{l}\text { follow- } \\
\text { up 期間 }\end{array}$ & $\begin{array}{l}\text { NY } \\
\text { HA }\end{array}$ \\
\hline \multicolumn{16}{|c|}{ Aortic } \\
\hline 1. & $\begin{array}{l}\text { 全身 } \\
\text { 呵吸 }\end{array}$ & 棬急 & 4 & $\begin{array}{l}\text { SR } \\
+\mathrm{VPC}\end{array}$ & $\mathrm{C}^{8 \mathrm{y} 11 \mathrm{~m}}$ & 剖検 & - & - & $\begin{array}{l}\text { small opening } \\
\text { hinge }\end{array}$ & - & - & $\begin{array}{l}\mathrm{BS} 19(\mathrm{~s}) \\
8 \mathrm{y} 11 \mathrm{~m} \text { 後死亡 }\end{array}$ & $亡^{-}$ & - & \\
\hline 2. & $\begin{array}{l}\text { 狭心痛, } \\
\text { 起坐 }\end{array}$ & $\begin{array}{l}\text { 呼吸困難 } \\
\text { 呼吸 }\end{array}$ & 4 & SR & $5 \mathrm{~m}$ & 透視 & 33 & 19 & $\begin{array}{l}\text { small opening } \\
\text { hinge }\end{array}$ & $0 \mathrm{~d}$ & ReAVR & $\begin{array}{l}\mathrm{BS} 25(\mathrm{~s}) \\
\rightarrow \mathrm{BS} 23(\mathrm{~s})\end{array}$ & 生 & 5 y $9 \mathrm{~m}$ & 2 \\
\hline 3. & 狭心痛 & 動悸 & 3 & SR & 3 y $11 \mathrm{~m}$ & 透視 & 約 $45^{*}$ & 約 $30 *$ & $\begin{array}{l}\text { small opening } \\
\text { aortitis }^{+}\end{array}$ & $2 \mathrm{~d}$ & ReAVR** & $\begin{array}{l}\mathrm{BS} 23(\mathrm{~s}) \\
\rightarrow \mathrm{SJM} 21\end{array}$ & 生 & $1 \mathrm{y} 6 \mathrm{~m}$ & 1 \\
\hline 4. & $\begin{array}{l}\text { 胸痛, } \\
\text { 風邪 }\end{array}$ & 息切れ & 2 & $\mathrm{SR}$ & $3 \mathrm{y} 10 \mathrm{~m}$ & 透視 & 31 & 13 & small opening & $4 \mathrm{~d}$ & 血栓除去 & $\begin{array}{l}\mathrm{BS} 21(\mathrm{~s}) \\
\rightarrow \text { そのまま G1 }\end{array}$ & GI 出血 & 1 y $6 \mathrm{~m}$ & 2 \\
\hline \multicolumn{16}{|c|}{ Mitral } \\
\hline 5. & $\begin{array}{l}\text { 全身倦急 } \\
\text { 脳梗塞 }\end{array}$ & $\begin{array}{l}\text { 呼吸困難 } \\
\text { 心停止 }\end{array}$ & 4 & $\begin{array}{l}\mathrm{SR} \\
\rightarrow \mathrm{Af}\end{array}$ & 7 y $5 \mathrm{~m}$ & 透視 & 30 & 24 & $\begin{array}{l}\text { 全周性 } \\
\text { small opening }\end{array}$ & $0 d$ & $\begin{array}{l}\text { ReMVR } \\
\text { (anat. TVI }\end{array}$ & $\begin{array}{l}\text { BS } 27(\mathrm{~s}) \\
\mathrm{R}) \rightarrow \text { SJM } 25\end{array}$ & 生 & $2 \mathrm{y} 6 \mathrm{~m}$ & 2 \\
\hline 6. & 全身倦总 & $\begin{array}{l}\text { 呼吸困難 } \\
\text { 塞栓症 }\end{array}$ & 2 & Af & $9 \mathrm{~m}$ & 透視 & 27 & 14 & LA 内 pannus ${ }^{+}$ & $7 d$ & ReMVR & $\begin{array}{l}\text { BS } 29(\mathrm{~s}) \\
\rightarrow \text { SJM } 29\end{array}$ & 生 4 & $4 \mathrm{y} 10 \mathrm{~m}$ & 2 \\
\hline 7. & $\begin{array}{l}\text { 突然の } \\
\text { 心停 }\end{array}$ & $\begin{array}{l}\text { 意識消失 } \\
\text { 止 }\end{array}$ & 1 & $\mathrm{SR}$ & 13 pod & 剖検 & - & - & $\begin{array}{l}\text { small opening } \\
\text { 極小さな血栓 }\end{array}$ & - & - & $\begin{array}{l}\text { BS } 25(\mathrm{~m}) \\
: 13 \text { pod 死亡 }\end{array}$ & $\dot{-}^{-}$ & - & - \\
\hline 8. & $\begin{array}{c}\text { TIA, } \\
\text { 呼吸困難 }\end{array}$ & $\begin{array}{l}\text { 後頭部痛 } \\
\text {, 起坐呼吸 }\end{array}$ & 4 & $\underset{\rightarrow \mathrm{AR}}{\mathrm{SR}}$ & 8 y $3 \mathrm{~m}$ & 透視 & 35 & 22 & $\begin{array}{l}\text { small opening } \\
\text { LA 内 pannus }\end{array}$ & od & ReMVR & $\begin{array}{l}\mathrm{BS} 27(\mathrm{~s}) \\
\rightarrow \text { SJM } 27\end{array}$ & 生 & $1 \mathrm{y}$ & 1 \\
\hline 9. & $\begin{array}{l}\text { 脳梗塞, } \\
\text { 胸水 }\end{array}$ & $\begin{array}{l}\text { 起坐呼吸 } \\
\text { 詝留 }\end{array}$ & 4 & Af & $5 y$ & 透視 & \multicolumn{2}{|c|}{$\begin{array}{l}\text { 閉鎖位で } \\
\text { 動がず }\end{array}$} & 全周性 & $0 \mathrm{~d}$ & ReMVR & $\underset{\rightarrow \operatorname{SJM}}{\mathrm{OS}} 25$ & $\begin{array}{l}\text { 病院死 } \\
\text { y } 8 \mathrm{~m} \text { 後 }\end{array}$ & 受 & - \\
\hline
\end{tabular}

Tricuspid

10. 全身倦急, 浮腫 3 Af $8 \mathrm{y} 6 \mathrm{~m} \mathrm{RA}$ 造影 markerなし large opening $2 \mathrm{~m}$ ReTVR BS $31(\mathrm{~s}) \quad$ 生 $5 \mathrm{y} 5 \mathrm{~m} \quad 3$ 胸部生迫感 $\quad$ pannus $^{+} \rightarrow \mathrm{BS} 29(\mathrm{~s})$ 気道狭窄

平均 $4 \mathrm{y} 9 \mathrm{~m}$.(剖検例を除く)，*他院での測定，**Thrombectomy を試みるも perivalvular leakage を来した. 平均 $3 \mathrm{y} 2 \mathrm{~m}$

な開放と閉鎖を行っていることがわかった．乙れに対し て症例 10 ではT弁のみ marker のない弁を使用してお り，単純透視のみでは弁の動きははっきりせず，RA 造 影を行って弁の動きが不良であるととがわかった.

心エコー検査のみでは血栓弁を診断できたあのはな く, 心カテーテル検査であ PCWP, PA 圧の上昇など の所見は得られるが確定部断とはならなかった，A弁で は LDH の上昇と貧血をきたした症例が 3 例あり，溶血 を示唆していた.

表 2 のごとく剖検例を含め大部分の症例で, small opening 亿血栓を認め, pannus の形成はM弁， T弁の 房室弁位の屯ので多く見られた，症例 7 ではm型 BS 弁 の small opening にごく小さな血栓を認めた．患者は 数分前までは担当医とべッドサイドで退院の話をしてい たが，突然廊下で倒れ，数秒後より開始された心蘇生に あかかわらず急性心不全で死亡した。

血栓弁晾断後 NYHA 4 度の 4 例はただちに緊急手 術を行い，他 3 例は 1 週間以内に準緊急手術を行った。 $\mathrm{T}$ 弁の症例 10 は患者の承諾に時間を要し， 2 か月後に 手術した． 8 例中 7 例に，初期 2 例は BS 弁で他 5 例は SJM 弁で再弁置換を施行した. 症例 4 は血栓除去のみ
で弁機能を回復できた，症例 3 む血栓除去は完全に行え たが，aortitis のためと思われる perivalvular leakage をきたしたため再弁置換を行った.

起坐位での挿管を行った症例もあったが，体外循環を 開始すると通常の再手術之同様に手術は行えた. 1 例に LOS のための IABP を挿入したが，全例急性期を乗り 越えた。 1 例を術後 1 年 8 か月目に呼吸不全で失ったが 他は術後平均 3 年 2 か月の現在, 再発することなく生存 している.

\section{考案}

人工弁置換後の血栓弁に上る弁機能不全は，機械弁に よる弁置換を行う限り起てるものであろう. 今回，10 例中 5 例で明らかに不適切な抗凝固療法が見られ，今 後，紹介医，患者の啓蒙が重要であると考える，BS 并 の血栓弁の頻度は，Björk ら ${ }^{2)}$ をはじめT位，M位， $\mathrm{A}$ 位の順之いう報告が多いが，抗凝固療法不良例が $\mathrm{A}$ 位 で多かったためか， S 型 BS 弁ではT位 6.3\%，A位 $1.6 \%$ ，M位 $0.8 \%$ の順之なった。

また, Altman ら ${ }^{3)}$, Sullivan ら ${ }^{4}$ 亿よる抗血小板剂の 併用により血栓塞栓症が激減したとの報告より，'84 年 
よりわれわれも warfarin に抗血小板剂を併用してい る. またとのころより機械弁の第一選択として SJM 弁 を使用している．乙のためか現在のところ SJM 弁の血 栓弁は経験していないが，追跡期間が短く，今後の検討 を要する.

症例 7 の位に $\mathrm{m}$ 型 BS 弁を置換した症例ではトロン ボテスト上抗凝固療法に原因があったとは考えられず, large opening を anterior すなわち左室流出路に向け, 収縮期に disc が良好に閉鎖するように考えたのが逆に 原因となったのかむしれない．Björk ら ら〉 は posterior を向けるほうが乱流が少ないとしている，血栓弁の䛦断 は cineradiography にて容易に行えた症例が多かった が，症例 9,10 のように marker がなくほとんど disc が動いていない症例では判断しにくく，初回弁置換術の control をとっておく必要性を感じた.

外科治療としては再弁置換術と血栓除去術がある. 簡
便であり，また内膜で被われた弁坐は新しい并坐より血 栓を生じにくいので可能なら後者を選ぶべきであるが， 実際には房室弁位では視野が悪く再弁置換術となること が多いようである．M位 ${ }^{6,7)}$ のものに大動脈切開を加 え，積極的に血栓除去を行った報告あある. Urokinase 等による血栓溶解療法は右心系の弁には今後試みるべき

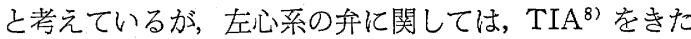
した報告ああり，外科治療を行っていく方針である.

文 献 1) 相馬康宏：心臟 12：463, 1980.2 2) Björk, V. O.: J. Thorac. Cardiovasc. Surg. 78: 331, 1979. 3) Altman, R.: J. Thorac. Cardiovasc. Surg. 72: 127, 1976. 4) Sullivan, J. H. : N. Engl. J. Med. 284 : 1391, 1971. 5) Björk, V. O.: Ann. Thorac. Surg. 18: 379, 1974. 6) Ayuso, L. A. J. Thorac. Cardiovasc. Surg. 84: 906, 1982. 7) Venugopal, P. : J. Thorac. Cardiovasc. Surg. 91: 168, 1986. 8) Graver, L. M. : Ann. Thorac. Surg, 46: 85, 1988.

\section{6 僧帽弁置換術後に発生した左房内血栓}

\begin{tabular}{|c|c|c|c|c|c|c|c|c|c|c|c|c|}
\hline & & & & & 久留米 & k大学 & 第 2 外科 & & & & & \\
\hline 中 & & 攻 & 麻 & 生 & & 公 & 西 & 義 & 勝 & 平 & 野 & 顕 \\
\hline 藤 & 文 & 彦 & 青 & 柳 & 成 & 明 & 小須賀 & 健 & - & 大 & 石 & 喜 \\
\hline
\end{tabular}

左房内血栓症は僧帽弁置換術後において最屯問題とな る合併症の一つである，その発生を防ぐために，教室で は術後の十分なる抗凝固療法を行ってきた. しかし，術 後遠隔期に 7 症例で左房内血栓を認めた. 今回とれらを 対象として，僧帽弁置換術後に左房内血栓を発生せしめ る因子と，その治療方釬について検討を加えた.

\section{対象と方法}

対象症例は僧帽弁置換術後遠隔期に左房内血栓を認め た 7 例である. 男性 3 例，女性 4 例で，年龄は 29 歳か ら 68 歳（平均 47.1 歳）であった. 僧帽弁病変は僧帽弁 狭窄症 (MS) 2 例，僧帽弁狭窄症兼閉鎖不全症 (MSr) 4 例，僧帽弁閉鎖不全症 (MS) 1 例であり, 合併病変 として大動脈弁病変を 3 例に，三尖弁閉鎖不全症を 6 例

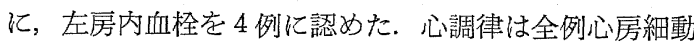
であった，手術は，2 例では左房切開により，5例では 右房切開による経心房中隔的に僧帽弁に達し，僧帽弁置
換術 (MVR) を行った.

使用した人工弁は生体弁 ( $\mathrm{CE}$ 弁) 2 例, 機械弁 ( $\mathrm{SJM}$ 弁，BS 弁） 5 例であった. 合併手術として大動脈弁置 換術 (AVR) を 3 例䎲，三尖弁輪縫縮術 (ATP) を 6 例 に，左房内血栓除去術を 4 例に行った. 左房縫縮術はい ずれにあ行わなかった，術後は，生体弁症例を除く5例 に対して, warfarin と Dipyridamole に上る永久的な 抗凝固療法を行った. 初回手術から左房内血栓発生まで の期間は 21 か月から 78 か月（平均 45.7 か月）であり， 7 例中 4 例では再手術で血栓除去術を行った（表 1 ）.

同時期に MVR を行い, 術後左房内血栓を認めず正 常人工弁機能を有する 53 例（生体弁 16 例, 機械弁 37 例）を対照群として無作意に抽出した，左房内血栓の発 生に関与する因子としては, 心調律, 術前後の CTR, 人工弁の種類, 術前における左房内血栓の有無, 僧帽弁 への到達法, 左房縫縮術の有無, および術前後の左房容 積を用い両群を比較した. 左房容積は Wilkins ${ }^{13}$ らの方 